\title{
Változások a családban
}

Orsolya Kolozsvari (2019): Gender, Marriage, Families - From the Individual to the Social. Kendall Hunt Publishing Company, Dubuque, 372 p.

\section{BÉRES ZSUZSA ${ }^{1}$ - LADANCSIK TIBOR ${ }^{2}$ - MASZLAG FANNI ${ }^{3}-$ NEMES-ZÁMBÓ GABRIELLA ${ }^{4}$}

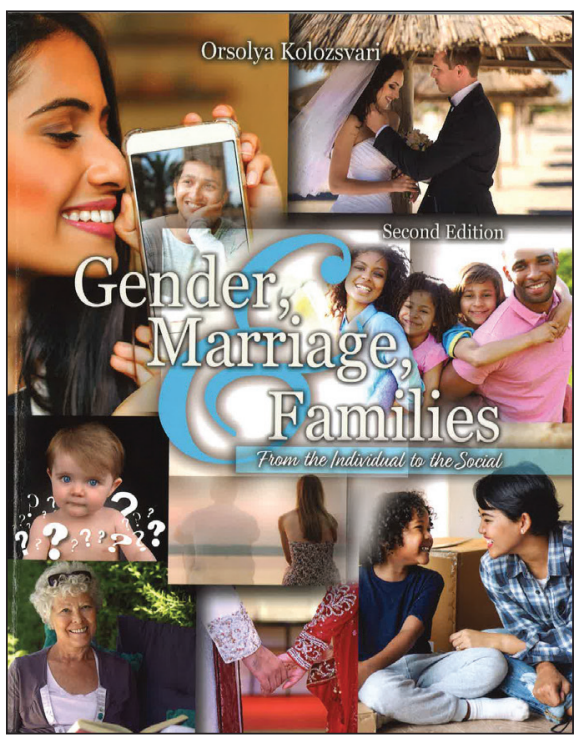

Hogyan változnak a párkapcsolatok és a családok az Amerikai Egyesült Államokban és szerte a világban? Recenziónkban egy jól felépített tankönyvről olvashatnak átfogó bemutatást, amely alapvetően a változásokra helyezi a hangsúlyt családon és párkapcsolaton belül. Ennek ellenére természetesen bizonyos frázisok állandóak maradtak a családszociológiában is.

A könyv tankönyvként nem egyetlen fótémát jár körbe, hanem családszociológiai és a társadalmi nemekre vonatkozó témákkal egyaránt foglalkozik, illetve akár a kulturális sokszínűséget oktató órákon is fölhasználható. A szerző egyedi (önmaga által kitalált) esettanulmányokkal dolgozik, amelyeket rövid szociológiai elemzésekkel, elméletekkel, statisztikai összefüggésekkel jelenít meg. Ez arra készteti a diákokat, hogy kapcsolatot találjanak 'egyéni' és 'társadalmi' között, és segítse őket a szociológiai perspektíva felismerésében. A könyv kiválóan támogatja az önálló tanulást is, minden fejezetet követően tartalmaz egy

${ }^{1}$ Doktorandusz, Debreceni Egyetem Humán Tudományok Doktori Iskola, Szociológia és Társadalompolitika Doktori Program, e-mail: beres.zsuzsa@arts.unideb.hu

${ }^{2}$ Doktorandusz, Debreceni Egyetem Humán Tudományok Doktori Iskola, Szociológia és Társadalompolitika Doktori Program, e-mail: ladancsik.tibor@arts.unideb.hu

${ }^{3}$ Doktorandusz, Debreceni Egyetem Humán Tudományok Doktori Iskola, Szociológia és Társadalompolitika Doktori Program, e-mail: maszlag.fanni@arts.unideb.hu

${ }^{4}$ Doktorandusz, Debreceni Egyetem Humán Tudományok Doktori Iskola, Szociológia és Társadalompolitika Doktori Program, e-mail: nemes.zambo.gabriella@arts.unideb.hu 


\section{RECENZIÓ}

kérdéssort, amely segíti az elmélyülést, az elgondolkodtatást és az olvasottak megértését. A könyv alapvetően három nagy egységben, összesen 16 fejezetben íródott.

Az első rész 8 fejezetből áll, és a romantikus kapcsolatokkal, valamint a házassággal foglalkozik. Beszél többek között az online kapcsolatokról, az ingázó házasságokról, a különböző rasszok közötti kapcsolatokról, családon belüli erőszakról, gyermektelenségről, az egyedül élésről mint családformáról, szakításokról és a különböző kultúrák különböző esküvői szokásairól. A második nagy egység négy fejezetben foglalkozik a családdal és a gyerekekkel a következő témákon keresztül: társadalmi nemek szerinti szocializáció, tini mamik, gyermekét egyedül nevelő szülő és a dolgozó anya.

A harmadik, egyben utolsó nagy egység a világszerte fellelhető más és más családtípusokról ír. Foglalkozik a transznacionális családokkal, a gyermekházassággal, a házassági hűtlenséggel, a poliamóriával és a poligámiával.

\section{A történetekről...}

A könyv első fejezete a párkapcsolati formákról és az eltérő családmodellekről szól. Olyan témákat ölel fel, mint például a nemzetileg vegyes párkapcsolatok, a távkapcsolatok, a szingli életstílus, vagy a családon belüli erőszak. Mindezek mellett a fejezet vitatott társadalmi témákat is feldolgoz.

A távkapcsolatok alfejezetben az esetleírás egy olyan fiatal házaspárról szól, akik egymástól távol élnek. A feleség, aki a történet narrátora is egyben, nem tudta befejezni az egyetemet, mivel tanulmányai közben rájött, hogy az egyetemet igazából a szülei miatt választotta. Munkába áll, megházasodik, közben pedig rájön, hogy csontkovács szeretne lenni, az ehhez szükséges diplomát azonban csak egy távoli városban tudja megszerezni. A saját szülei ellenzik a váltást, emellett anyósa sem örül a híreknek, férje és apósa viszont támogatja. Férje otthon marad saját munkája miatt, ő viszont albérletbe költözik. A fejezet a távkapcsolatok nehézségeit írja le. Anyagilag elég megterhelő a fiatal házaspárnak, mivel két háztartást kell fenntartaniuk, emellett a távollét is megterhelő mindkettőjük számára. Több távkapcsolattal is találkozhatunk a fejezet során, mivel csatlakozik egy távkapcsolatokat segítő csoportba. Itt láthatjuk, hogy a távkapcsolatok legfőbb kiváltó oka a munkavállalás, azonban nagyon eltérő társadalmi csoportokat is érinthet, olyannyira, hogy az egyes helyzetek szinte összehasonlíthatatlanokká válnak.

Az egyedül élés terjedő jelenségével szintén egy alfejezet foglalkozik. A fejezetben különböző példákon keresztül mutatja be a szerző, hogy az egyes életszakaszokban milyen külső vagy esetleg belső kényszerek, motivációk miatt választja valaki az egyedül élést mint életformát. Az első történetben egy 29 éves lányt, Mackenzie-t ismerhetjük meg. Mackenzie egy 4 gyermekes, vidéken élő, alsó társadalmi osztályból jövő család harmadik gyermeke. Mióta csak az eszét tudta, mindig osztozkodnia 


\section{RECENZIÓ}

kellett mindenen, a fürdőszobán, a szobáján és a ruháin is. Mikor felvették az egyetemre, kollégista lett, ami egyet jelentett azzal, hogy szobatársat kapott. Nem volt szerencsés helyzetben, mivel nem jöttek ki jól a szobatársával, ezért egy év után, mikor lehetősége nyílt, kiköltözött albérletbe. Az albérletben hárman voltak, azonban Mackenzie-nek végre saját szobája és fürdőszobája volt. Az egyetemi évei befejeztével munkát talált, egyedül bérelt ki egy lakást, majd három év kemény munka és spórolás után vett egy saját lakást. Az egyedül élésnek köszönhetően Mackenzie sokkal jobban megismerte önmagát. Mindeddig csak úgy ismerte magát, mint valakinek a lánya, testvére, szobatársa, barátnője, barátja, aki kapcsolatban áll valakivel. Mindig mások kívánságait, életét, preferenciáját helyezte a sajátja elé, nem volt lehetősége, hogy mélyebben megismerje magát, saját kívánságait. Most érezte legelőször magabiztosnak, harmonikusnak önmagát, ami által kiegyensúlyozottabb lehet a társadalmi élete is.

Janet egy 59 éves egy gyermekes pszichiáter, akit elhagyott a férje egy fiatalabb nőért, mikor lányuk 6 éves volt. Sokáig maga alatt, magányosan és megtörten nevelte lányát, de igyekezett mind munkahelyén, mind anyaként helyt állni. Mikor lánya lediplomázott és elköltözött egy másik államba, akkor tudatosult benne, hogy mint anya, akire minden nap szüksége van a lányának, megszűnik. Hirtelen üresség támadt benne és valami új kihívás elé akarta állítani magát. Új életcélja lett, Ugandába ment, hogy segítsen a betegeken. Itt olyan új látásmódot kapott, amit hazatérte után beépített mindennapi életébe is. Úgy döntött, hogy eladja régi házát és elköltözik egy másik államba. Vett egy új házat, amit végre saját ízlésének megfelelően rendezhetett be, szép nagy kerttel. Szeretett otthon lenni egymaga, a kertjében tevékenykedni, azonban megismerkedett egy férfival, akibe beleszeretett. Évekig tartott a kapcsolatuk, mikor Clint megkérte Janet kezét, de Janet nem szerette volna feladni ezt az új életformát, amiben most élt. Sokkal kiegyensúlyozottabbnak, nyugodtabbnak, élettel telibbnek, bölcsebbnek érezte magát, mint valaha.

A szerző arra a megállapításra jutott, hogy az alapvető demográfiai irányzatok - a tartósan csökkenő, korösszetételében öregedő népesség, a születések és a házasságkötések számának hanyatlása, illetve alacsony szintje, a párkapcsolatok stabilitásának gyengülése - közvetett módon, de hatással vannak a családformákra. Megváltoztatták annak összetételét, típusait. Mindezen folyamatok eredményeit, illetve következményeit mintegy tükörként tárja a társadalom és így az olvasó elé is.

Azt gondolhatnánk, hogy ezek az új jelenségek mindig egy adott generációra jellemző trendek, ugyanakkor ez nem így van. Ha vesszük az egyedüllét fogalmát, leginkább az időskorúak körében jellemző problémaként észleljük, és ez alapvetően igaz is. A fiatalok körében azonban van ennek is egy terjedő változata, amit a tudatosan vagy az akaratlanul vállalt tartós párkapcsolat nélküli életforma és az ezzel együtt járó egyedüllét jellemez. 


\section{RECENZIÓ}

A könyv Családok gyermekekkel címet viselő második fejezete négy altémával szólítja meg az olvasót. A történetek mindegyike aktuális társadalmi kérdésékkel foglalkozik, az esetek jórésze mégis sok évre, évtizedre visszavezethető, társadalmi, gazdasági és politikai kontextusba ágyazott normákat, értékeket, attitűdöket állít középpontba. A fejezet egyik legmeghatározóbb és összetettebb történetében a társadalmi nemi szocializáció témájával, az ahhoz kapcsolódó alapvető fogalmakkal, viszonyulásokkal és normákkal ismerkedhetünk meg.

Más, legalább ennyire hangsúlyos témákat is felvet a szerző a történeteken keresztül, többek között két eset erejéig a tinédzser terhességgel is foglalkozik. A két történet azonos jelenséget jár körül, de mégis két ellentétes pólust világít meg. Sierrát megismerve betekintést nyerünk egy tini lány életébe, aki nem csak tini kismamává válik, hanem egyben feltételezett szexuális bántalmazás áldozata is lesz. Egy, a szülei elől elhallgatott középiskolai buliban összetalálkozik egy számára nagyon kedves fiúval. Az este egy bizonyos pontján azonban eszméletét veszti, az első alkoholfogyasztási élménye súlyos következményekkel jár. Néhány hétig nem érzékel különösebb változást a testén és nem merül fel benne semmilyen kétely az estével kapcsolatban, hiszen míg magánál volt, nem történt semmi olyan, ami aggodalomra adott volna okot, majd mikor magához tért a házibuli egyik szobájában, egyedül, felöltözve ébredt. Miután azonban változásokat észlel a testében, gyanakodni kezd, hogy a szóban forgó este talán mégsem úgy zajlott, ahogyan azt ő képzelte. Terhességi tesztet vásárol, aminek eredménye megerősíti gyanúját, gyermeket vár. Az említett fiú számonkérése nem jár eredménnyel, a fiú tagadja a történteket és nem mutat hajlandóságot arra, hogy segítsen feltárni az este valós történéseit. A történet további folytatását nem ismerjük meg, a könyv által alkalmazott történetmesélési technika eléri a kívánt célt: az olvasóban számos verzió megfogalmazódik a történet végének fejtegetése során. Mindez azonban nemcsak a történetvezetés szempontjából a könyv egyik fontos ismérve, hanem a történetek diverzitásának, az esetek komplexitásának érzékenyítő funkcióját is erősíti.

A témakörben ezen túl egyszülős családok mindennapjaiban felmerülő problémakörökkel, az egyszülős családok társadalmi megítélésével, valamint a dolgozó anyákkal szembeni előítéletekkel is találkozhatunk. A szerző ebben a fejezetben is kérdésekbe ágyazva igyekszik szerepeltetni a témához kapcsolódó legfontosabb elméleti alapokat, amely hasonlóan hatékony technikának minősül, mint a fentebb említett befejezetlen történet technikája. Mindehhez az olvasó érdeklődését fokozva kutatói feladatokat javasol az adott témában.

A könyv harmadik nagy egysége a különböző, világszerte fellelhető családokról és családtípusokról ír, így többek között szót ejt a határokon átívelő családokról, a gyermekházasságról, de a monogámián túl a poliamóriáról és a poligámiáról is. A szerző a könyvet záró négy fejezetben - csakúgy, mint a könyv előző egységeiben - aktuális, gyermekeket és felnőtteket egyaránt érintő problémákat vet fel, amelyekhez hallgatóként többeknek lehet kapcsolódása. Ezen esetek egyike például a mexikói Rocio 


\section{RECENZIÓ}

története, aki az Amerikai Egyesült Államokban él és dolgozik, miközben a családja otthon van, Mexikóban. A megélhetés, a jobb életkörülmények megteremtése miatt mások gyermekeit neveli 0-24 órában, miközben őt is hazavárják a gyerekei és a férje, akikkel már évek óta nem találkozott. Rocio illegálisan került az USA-ba egy jobb élet megteremtésének reményében, akárcsak más dadus ismerősei, akik Európából érkeztek. Olyan családok gyerekeit nevelik olyan házakban és körülmények között, amilyenre ők is vágynak, amit a gyerekeiknek szeretnének. De hasonló helyzetben van az erdélyi Attila is, aki Németországban kénytelen dolgozni azért, hogy a gyermekeinek 21. századi életszínvonalat biztosíthasson. Négy hét külföldön, távol a családtól, három hét közösen, együtt eltöltött idő. Családok, akik a megélhetés miatt kényszerülnek földrajzi értelemben kettészakadni, gyerekek, anyák és apák, akik hazavárják szüleiket és társaikat. Állandó aggodalomban és félelemben élnek, hogy elveszíthetik szeretteiket, a távolság közéjük áll. De nincs más választásuk. Nincs?

Kolozsvári Orsolya tankönyvének második kiadása nagyon pontos egyéni életutakat és családrajzokat mutat be különböző elgondolkodtató történeteken keresztül, amelyek megalapozott szakirodalmakra és statisztikai adatokra épülnek. A világ különböző tájairól gyűjtött és írt történetek korhű ábrázolásai a 21. századi családnak, problémáival és nehézségeivel együtt. Az egyes fejezetek végét záró összegző kérdések pedig mindenki számára lehetővé teszik az olvasottakban való elmélyülést, továbbgondolást, amely a kényesebb témák érzékenyítésében alapvető lehet a tanórák folyamán is. 